Supplement of The Cryosphere, 8, 877-889, 2014

http://www.the-cryosphere.net/tc-8-877-2014/

doi:10.5194/tc-8-877-2014-supplement

(C) Author(s) 2014. CC Attribution 3.0 License.

(c) (i)

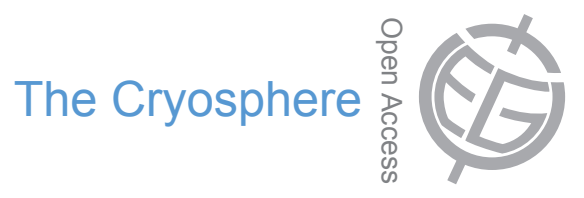

Supplement of

\title{
Bathymetric and oceanic controls on Abbot Ice Shelf thickness and stabil- ity
}

J. R. Cochran et al.

Correspondence to: J. R. Cochran (jrc@1deo.columbia.edu) 


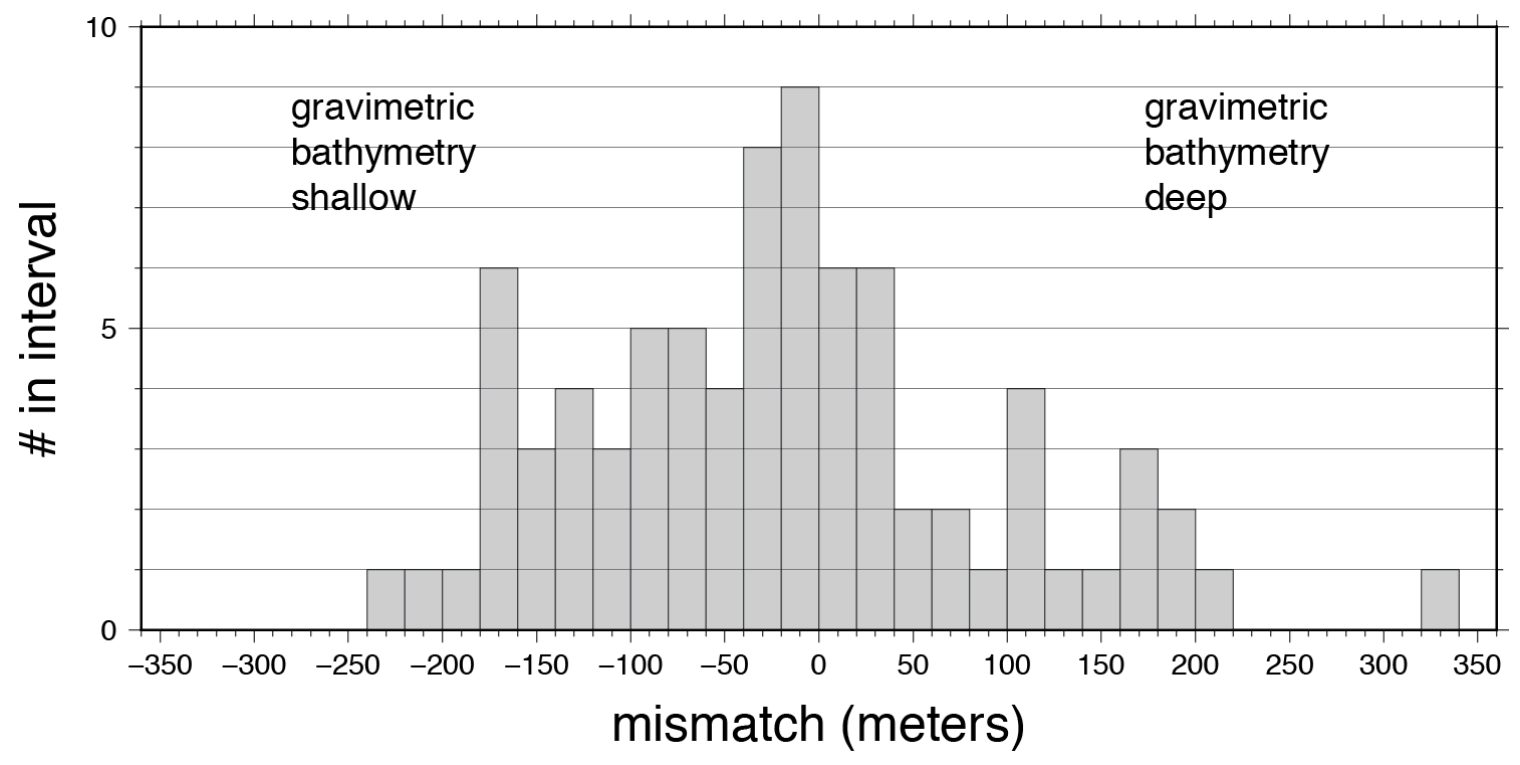

Figure S1: Distribution of mismatches between gravimetrically [Cochran and Bell, 2012] and seismically [Brisbourne et al., 2014] determined bathymetry beneath the Larsen C Ice Shelf. The gravimetric bathymetry was determined by inversion of NASA Operation IceBridge gravity data using the Parker/Oldenburg technique [Oldenburg, 1974] and assuming a uniform crustal density of $2.7 \mathrm{~g} / \mathrm{cm}^{3}$ and a mean depth of $535 \mathrm{mbsl}$ in the area of the inversion [Cochran and Bell, 2012]. No sediment layer was included. The seismically determined depths are determined from the two-way travel time of reflected sound waves generated by explosions and recorded on geophones. The sound velocity in the upper $100 \mathrm{~m}$ of ice was determined from three seismic refraction lines and velocities of $3812 \mathrm{~m} / \mathrm{s}$ and $1445 \mathrm{~m} / \mathrm{s}$ were assumed for the lower part of the ice and the water column, respectively [Brisbourne et al., 2014. The grid of gravimetrically determined depths was sampled at the locations of the seismic reflection measurements to determine the mismatch. The standard error of the gravimetric depths relative to the seismic depths is $59.0 \mathrm{~m}$ with $60 \%$ of the differences less than $100 \mathrm{~m}$.

\section{References Cited}

Brisbourne, A. M., A. M. Smith, E. C. King, K. W. Nicholls, P. R. Holland, and K. Makinson (2014), Seabed topography beneath Larsen C Ice Shelf from seismic soundings, The Cryosphere, 8, 1-14, doi:10.5194/tc-8-1-2014. 
Cochran, J. R., and R. E. Bell (2012), Inversion of IceBridge gravity data for continental shelf bathymetry beneath the Larsen ice shelf, Antarctica, J. Glaciology, 58, 540-552, doi:10.3189/2012JoG11J033.

Oldenburg, D. W. (1974), The inversion and interpretation of gravity anomalies, Geophysics, 39, 536-536, 